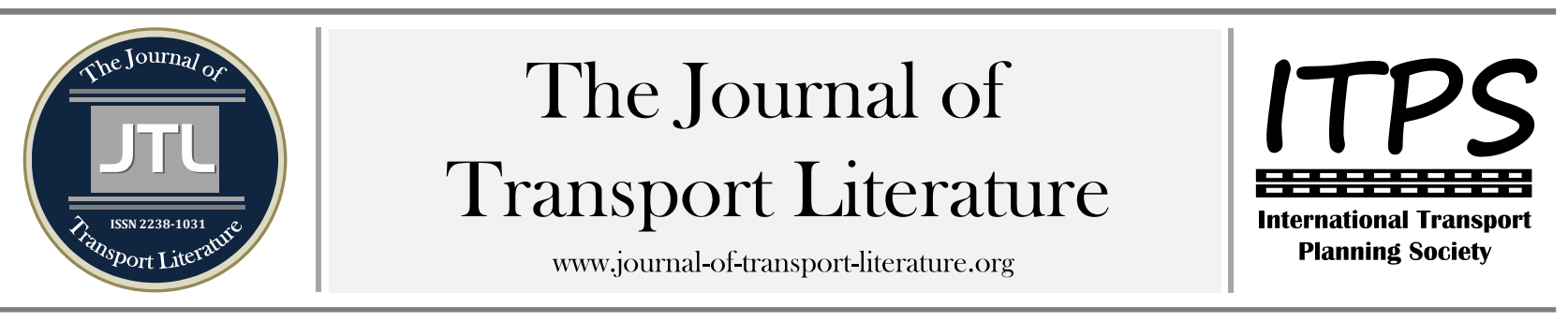

\title{
The scientific research context of urban transports for Bus Rapid Transit systems applications
}

\author{
Alvaro Luiz Neuenfeldt Júnior ${ }^{1,+}$; Julio Cezar Mairesse Siluk²; Sabine Ritter De Paris ${ }^{3}$ \\ 1 Universidade do Porto, Porto, Portugal \\ 2 Universidade Federal de Santa Maria, Santa Maria, Brasil \\ 3 Universidade do Porto, Porto, Portugal
}

\section{Article Info}

Keywords:

Urban transports

Bus Rapid Transit

Production Engineering

Transports Engineering

Submitted 30 Jun 2015;

received in revised form 5 Jul 2015;

accepted 12 Jul 2015

Licensed under

Creative Commons

CC-BY 3.0 BR.

\section{Abstract}

Across history, transportation of people and cargo has been highly relevant for economic and social development, directly reflecting the evolution of how society is organized, culminating in the current forms of urban demographic organizations. Therefore, studies regarding urban mobility optimization are nowadays very relevant to scientific community. Hence, the main objective of this study is to identify the scientific context of urban public transport management for applications focused on Bus Rapid Transit systems (from 2009 to 2014), allowing visualization of possible opportunities to increase the level and number of contributions to these systems, through the development of a bibliometric analysis. It was possible to conclude that six articles are directly linked with this research field, establishing the theoretical framework to conduct further studies.

+ Corresponding author. Rua Dr. Roberto Frias 4200 - 465 Porto, Portugal

E-mail address: alvaroj.eng@gmail.com

\section{Introduction}

Across history, transportation of people and cargo has been highly relevant for economic and social development, directly reflecting the evolution of how society is organized, culminating in the current forms of urban demographic organizations (Duarte et al. 2012, Vasconcellos 2012).

Specifically, among the various ways that people move from one place to another, two different groups can be highlighted. The first is related to public transport, via tires (bus), railways (trains, subways, light rail and trolleys), or water (boats and ships), through previously stipulated routes, with scheduled times for arrival and departure, being (in theory) available to all urban center populations (UFPR 2012, Vasconcellos 2012, Murça and Muller 2014).

The second group, defined as private, is characterized by displacements that involve cars, motorcycles, bicycles, or even locomotion on foot, in a way that the main advantage is the versatility of transportation at any time for all required places. However, for cars and motorcycles, there is an extra demand, i.e, the space to keep the vehicles, which is significantly higher than public formats, mainly because of its lower unit optimization per habitant (Boareto 2007, Duarte et al. 2012).

Therefore, uncontrolled urban growth might generate conflicts among the different transportation models, in a manner that in some countries (e.g., Brazil), the use of private transport transportation might be emphasized over public transportation, which generates expensive costs in improvement and maintenance of road structures instead of the basic premises of urban mobility that accentuate social inclusion through the viable access of existing public spaces in a local community (Kittelson \& Associates et al. 2007, Wright and Hook 2007, Neuenfeldt Júnior et al. 2015).

The main objective of this study is to identify the scientific context of urban public transport management for applications focused on Bus Rapid Transit (BRT) systems, allowing visualization of possible opportunities to increase the level and number of contributions to these systems.

In summary, the BRT system is currently one of the most widespread public transportation systems, regarded as one of the best alternatives in terms of mass passenger displacement, focused on the improving socio-economic dynamics of cities, rationalizing resources, especially as opposed to individual motorized forms (Kittelson \& Associates et al. 2007, Wright and Hook 2007, NTU 2011).

This work is organized into three sections: the introduction (the current section), the research methods and results (section 2), and the conclusions, future work, and study limitations (section 3).

\section{Research methods}

To accomplish the objectives of this study, we adopted the methodological procedures shown in Figure 1. Using some definitions from Da Silva et al. (2010), Pizzani et al. (2010), Yoshida (2010), Beuren and Miguel (2013), Oliveira and Boente 
(2012), and Kubota et al. (2013), we aimed to elucidate the scientific context of our research topic, providing theoretical basis for later discussions about the results.

\begin{tabular}{|c|c|c|c|c|}
\hline \multirow[t]{9}{*}{$\begin{array}{l}\text { Definition of the } \\
\text { study field }\end{array}$} & $\begin{array}{c}\text { Research } \\
\text { paramentrization }\end{array}$ & $\begin{array}{l}\text { Articles portfolio } \\
\text { selection }\end{array}$ & $\begin{array}{l}\text { Bibliometric } \\
\text { analysis }\end{array}$ & Trend Analysis \\
\hline & Unit of analysis & $\begin{array}{l}\text { Duplication } \\
\text { exclusion }\end{array}$ & $\begin{array}{l}\text { Articles by } \\
\text { journal }\end{array}$ & $\begin{array}{l}\text { Parameterization } \\
\text { of the themes }\end{array}$ \\
\hline & $\begin{array}{l}\text { Research } \\
\text { cronology }\end{array}$ & $\begin{array}{l}\text { "Portfolio } \\
2 "\end{array}$ & Articles by author & $\begin{array}{l}\text { Themes by } \\
\text { publication }\end{array}$ \\
\hline & Articles language & Tittles conformity & Articles by year & $\begin{array}{l}\text { Choice of the } \\
\text { target theme }\end{array}$ \\
\hline & Material type & $\begin{array}{l}\text { Abstracts } \\
\text { conformity }\end{array}$ & & $\begin{array}{c}\text { "Portfolio } \\
4 "\end{array}$ \\
\hline & Keywords & $\begin{array}{l}\text { Citations } \\
\text { verification }\end{array}$ & & $\begin{array}{l}\text { Subthemes } \\
\text { specification }\end{array}$ \\
\hline & $\begin{array}{c}\text { "Portfolio } \\
1 "\end{array}$ & $\begin{array}{c}\text { "Portfolio } \\
3 "\end{array}$ & & AFs specification \\
\hline & & & & $\begin{array}{l}\text { Choice of the } \\
\text { target subtheme }\end{array}$ \\
\hline & & & & $\begin{array}{c}\begin{array}{c}\text { "Portfolio } \\
5 "\end{array} \\
\text { Relation of target } \\
\text { subtheme and } \\
\text { AFs }\end{array}$ \\
\hline
\end{tabular}

Figure 1 - Research methods steps.

For the data mining steps, parameterization of the search tools used was proposed, so we chose to use the Coordenação de Aperfeiçoamento de Pessoal de Nível Superior - CAPES. This unit of analysis was fundamental due to its capacity to add repositories of articles from the most relevant global scientific indexes, such as Scopus ${ }^{\circledR}$, Web of Knowledge $\AA$, Science Direct $\AA$, Emerald $\AA$, Elsevier $\AA$, and Springer $®$. Thus, we can define the chronological period for the study, between 2009 and 2014, in conjunction with the language (any) and material type (only journal articles).

Afterwards, we defined the terms that best represented the urban transportation topic, based on the presumptions described by Duarte et al. (2012), Kittelson \& Associates et al. (2007), Wright and Hook (2007), NTU (2011), and Vasconcellos (2012). Based on these papers, we chose the following keywords: "urban mobility" and "public transport"; the first yielded 891 papers, a number considered representative for composing "Portfolio 1".

For the article selection, we first excluded some improper occurrences, such as duplicate instances, reviews, reissues of earlier articles, announcements, event articles, complete books, and book chapters, to refine the research and only use researches published in scientific journals, thus forming the second set of 651 items ("Portfolio 2").

We then read titles and, in more detail, the abstracts of all selected works, to filter the occurrence of materials that had no direct correlation to the study field, leaving a total of 260 items that composed "Portfolio 3", ordered by citation relevance, according to the database available in Google Scholar®. After these steps, it was possible to elaborate the final article list, organized in electronic sheets, facilitating data compilation.

For the bibliometric analysis step, the characteristics of each article were detailed to enable the visualization of attributes to infer information about the background of the field of study.

We then compiled the data to see which of the 127 journals publish the most articles related to portfolio management theme ("Portfolio 3"), with number one being the Journal of Transport Geography (24 publications), followed by TeMA: Journal of Land Use, Mobility and Environment (21) and Transport Policy (18), according to Table 1.

Table 1 - Main journals indexed by article in the "Portfolio 3".

\begin{tabular}{ll}
\hline Journal & Articles \\
\hline Journal of Transport Geography & 24 \\
TeMA: Journal of Land Use, Mobility and Environment & 21 \\
Transport Policy & 18 \\
Research in Transportation Economics & 12 \\
Transportation Research Part B & 9 \\
Transportation Research Part A & 7 \\
Transportation Research Part C & 5 \\
\hline
\end{tabular}

In a general way, the concentration level of more than one article per journal was $65.77 \%$, above initial expectations, because of the diversity of this topic, which can fit an extensive list of the scopes and aims of different scientific journals, in the transports area or not.

Regarding the list of articles categorized by author, four were linked to Adriana Galderisi (Galderisi 2009, Galderisi and Ceudech 2010a, Galderisi and Ceudech 2010b, and Galderisi 2011), regarding sustainability and implantation of transformation policies in transports, correlated with the European urban area context.

With the same number, Alejandro Tirachini (Tirachini et al. 2010a, Tirachini et al. 2010b, Tirachini and Hensher 2011, and Tirachini et al. 2014) specified the forms in which the interrelations and the behavior of many urban public models can occur. Also, with three publications, Romano Fistola (Fistola et al. 2009, Fistola 2011a, and Fistola 2011b) explored the water and air pollution effects caused by public transports in urban centers and it consequences the local population's quality of life. 
Regarding the dispersion of the material contained in "Portfolio 3" during the period of 2009-2014, Figure 2 shows a significant difference between the production values in the first half of the period (2009 to 2011) (average: 34) compared to 2012 and 2013 (average: 68). Therefore, there was 100\% growth from the first to the second half of the whole considered period, mainly because of the increasing interest of the scientific community in collaboration, which allowed a better performance of the public transport systems, especially for public over private models.

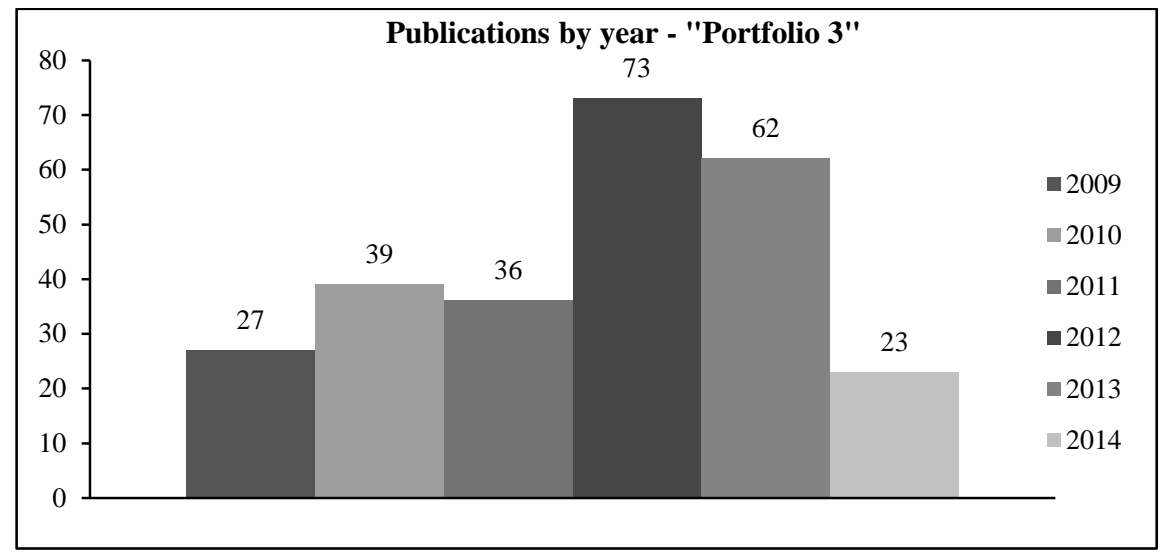

Figure 2 - Publications distribution by year of "Portfolio 3".

For 2014, is expected that there will be at least as many publications as the amount obtained in 2013 (62), thus reflecting the maintenance of the current interest observed in the last three years, consolidating this as a vanguard issue for the scientific community.

The next step verified the subjects with the most potential for new researches. This tendency analysis aims to elucidate the most relevant theme in the study field and the most common types of surveys adopted, enabling the exploration of scientific gaps that can be explored in future studies.

In a first instance, the articles were divided into five categories: "Sustainability", "Public transports", "Urbanism", "Culture", "Technology", and "Human resources", based on the bibliographical references previously mentioned.

According to Table 2, about a third of the publications were characterized as strongly in favor of "Sustainability" (69), followed by "Public transports" (56), "Urbanism" (43), and "Culture" (42). "Technology" (31) and "Human resources" (19) together comprised $19.23 \%$ of the total items in "Portfolio 3". In order to understand the evolution of the publications over time, we stratified the publications by each theme in complete years (2009-2014), which generated the results shown in Figure 3.

\begin{tabular}{lll} 
Table 2 - "Portfolio 3" articles distribution by theme. \\
\hline Theme & Articles & Percentage \\
\hline Sustaintability & 69 & $26,54 \%$ \\
Public transports & 56 & $21,54 \%$ \\
Urbanism & 43 & $16,54 \%$ \\
Culture & 42 & $16,15 \%$ \\
Technology & 31 & $11,92 \%$ \\
Human resources & 19 & $7,31 \%$ \\
\hline
\end{tabular}

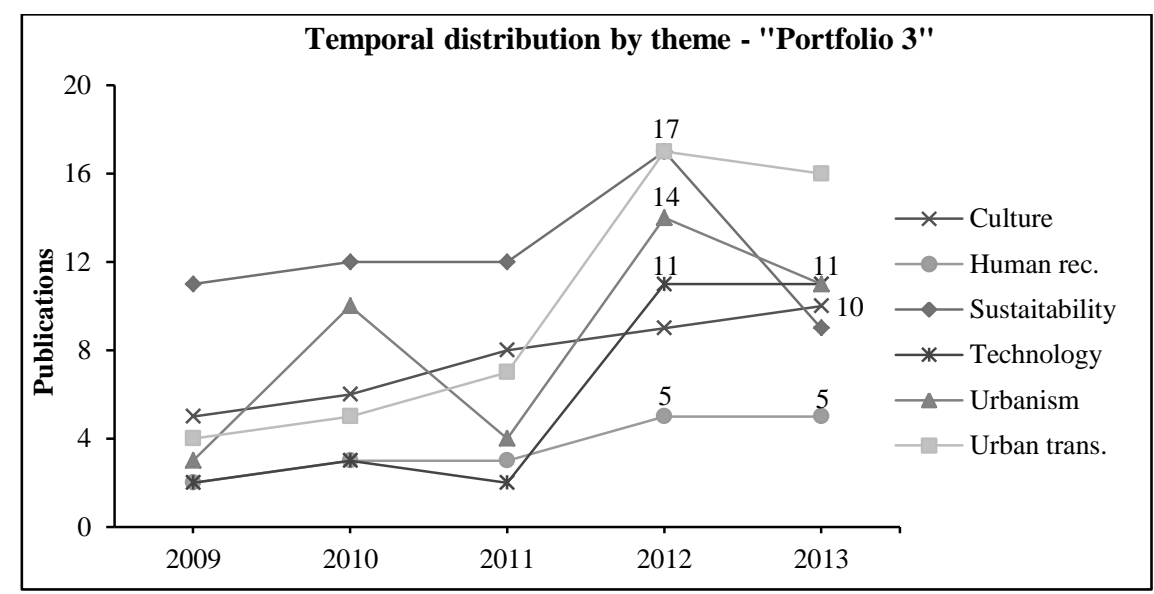

Figure 3 - "Portfolio 3" articles temporal distribution.

Consistent with the focus of this research, which aimed to check the bibliographic context of scientific production related to BRT, it was proposed to detail the information about the articles' profiles related to the thematic target "Urban transports", contained in the repository referred as "Portfolio 4", which yielded 57 items.

In the second step, these were divided into eleven subthemes ("Bicycles", "Intermodals", "Traffic control", "BRT", "Railroad transports", "Traditional buses", "Health", "Simulation", "Costs", "Motorcycles", and "Non-motorized") and four 
Applications Frameworks (AF) ("Case study”, "Multiple case study", “Technological development”, and "Literature review”), which were accounted as shown in Table 3, according to the intrinsic characteristics of each article.

Table 3 - "Portfolio 4" articles distribution by theme.

\begin{tabular}{llll}
\hline Subtheme & Articles & Application (AF) & Articles \\
\hline Bycicles & 11 & Case study & 31 \\
Intermodals & 11 & Multiple case study & 21 \\
Traffic control & 8 & Technological develop & 3 \\
BRT & 6 & Literature review & 2 \\
Railroad transp. & 6 & & \\
Traditional buses & 4 & & \\
Health & 3 & & \\
Simulation & 3 & & \\
Costs & 2 & & \\
Motorcycles & 2 & & \\
Non-motorized & 1 & & \\
\hline
\end{tabular}

Most items are related to case studies (31) or multiple case studies (21), specifically for "Bicycles" and "Intermodals", each with 11 publications, and about one-fifth (19.20\%) of the distribution comes from researchers affiliated with North American institutions, mainly due to know-how in that country regarding the management of public transport, as well as having the world's greatest economic and scientific potency, followed by Australian institutions.

The last step of the bibliometric study consisted of verifying the subtheme target characteristics, exclusively, for "BRT system" applications. This stratification generated "Portfolio 5", which had six articles. Its profiles regarding the application framework, frequency, and number of citations are shown in Table 4.

Table 4 - "Portfolio 5" publications related to the subtheme "BRT".

\begin{tabular}{llll}
\hline Author & Year & Citations & Application (AF) \\
\hline Munoz-Raskin & 2010 & 46 & Case \\
Currie and Delbosc & 2011 & 15 & Multicases \\
Mejia-Dugand et al. & 2013 & 5 & Multicases \\
Filipe and Macário & 2013 & 0 & Multicases \\
Schmid & 2014 & 0 & Multicases \\
Lee et al. & 2011 & 0 & Case \\
\hline
\end{tabular}

First, Munoz-Raskin (2010) studied the relationship between urban points of Bogota that are covered by BRT lines and the value of the residences located on these points over the years. Currie and Delbosc (2011) explored the ways in which the BRT design features, among other influences, significantly increased the number of passengers and the impact levels of service through a series of regression models held at 77 BRT and non-BRT routes in Australia.

Mejia-Dugand et al. (2013) explored perspectives on the adoption of BRT in different cities of Latin America and the geographical dissemination of these changes through the study of a time data series. Filipe and Macário (2013) described the results of reflection on an initial evaluation of how government policies are used to carry out BRT projects to understand which are the most used measures and objectives stated in this practice.

Schmid (2014) presented a model formulated to cover the problem of urban engineering design of BRT systems, from the establishment of a fixed number of pre-determined public manager's routes. Finally, Lee et al. (2011) found the constraints related to BRT implementation in Busan, South Korea, which concluded that, for such action be successfully fulfilled, it should be noted with exigencies related to the early stages of the preliminary selection of the location of corridors.

Thus, through the proposed stratification, from "Portfolio 1" to "Portfolio 5", 99.33\% of the surveyed articles, and only the six described in Table 4, are directly linked to the study of this research field, thus forming the theoretical and scientific set to conduct new works.

\section{Conclusion}

It was observed that there is still room for research focused on public transport, especially for the BRT context, where we observed the existence of only six studies with this focus.

In order to argue the possibility of a wide field for exploration, especially for issues related to ways to optimizing the public spaces required for urban displacements to occur in the most optimized way possible, there is a need to develop techniques to promote the performance evaluation of installed systems.

Thus, it can be stated that urban transportation as a topic still needs to be developed in terms of scientific research. Regarding opportunities for further research, it is expected that, in the future, tools oriented to the topic should be developed and applied to solve some management problems about Transport Engineering systems, according to the context of the study.

Regarding limitations, the product obtained with the research was directly related to the level of data and information provided by the portals (CAPES ${ }^{\circ}$ and Google Scholar $®$ ), although they are considered as the most complete and comprehensive currently available to the scientific community. 


\section{References}

Beuren, F. H., Ferreira, M. G. G. \& Miguel, P. A. C. (2013). Product-service systems: a literature view on integrated products \& services. Journal of Cleaner Production, 47, 222-231.

Boareto, R. (2007). Caderno de referência para elaboração de Plano de Mobilidade por Bicicleta nas Cidades. Brasília (BR): Secretaria Nacional de Transporte e da Mobilidade Urbana.

Castañon, U., Castañon, J. A. B. \& Santos, M. P. S. (2012). The profile of cyclists in the city of Juiz de Fora. Work (Reading, Mass.), 41, 58665870 .

Currie, G. \& Delbosc, A. (2011). Understanding Bus Rapid Transit route ridership drivers: An empirical study of Australian BRT systems. Transport Policy, 18(5), 755-764.

Da Silva, A. J., Toledo Filho, J. R. \& Pinto, J. (2010). Análise Bibliométrica dos Artigos sobre Controladoria Publicados em Periódicos dos Programas de Pós-Graduação em Ciências Contábeis Recomendados pela CAPES. ABCustos, 4(1), 1-17.

De Assis, U. W. (2012). VLT: A sustainable solution to urban mobility, in Joao Pessoa-PB. Work (Reading, Mass.), 41, $2169-2174$.

Duarte, F., Sánchez, K. \& Libardi, R. (2012). Introdução à mobilidade urbana. Curitiba (BR): Juruá.

Filipe, L. N. \& Macário, R. (2013). A first glimpse on policy packaging for implementation of BRT projects. Research in Transportation Economics, 39(1), 150-157.

Fistola, R., Gallo, M. \& La Rocca, R. A. (2009). Urban Mobility \& Polluting Emissions: Impacts on Public Welfare. TeMA : Journal of Land Use, Mobility \& Environment, 2(2), 20-30.

Fistola, R. (2011a). With the sun, with the air \& with the water: Urban mobility when the oil will end. TeMA : Journal of Land Use, Mobility \& Environment, 4(2), 10-20.

Fistola, R. (2011b). The City from the Wire the Aerial Cable Transport for the Urban Mobility The City from the Wire the Aerial Cable Transport for the Urban Mobility. TeMA : Journal of Land Use, Mobility \& Environment, 3(0), 10-20.

Galderisi, A. (2009). Parking Policies \& Quality of Urban Environment. TeMA: Journal of Land Use, Mobility \& Environment, 2(1), 10-20.

Galderisi, A. \& Ceudech, A. (2010a). Soft Mobility \& Pedestrian Networks in Urban Areas. TeMA: Journal of Land Use, Mobility \& Environment, 3(SP), 21-28.

Galderisi, A. \& Ceudech, A. (2010b). The city logistics within the transformation process of east Naples. TeMA: Journal of Land Use, Mobility \& Environment, 3(2), 20-30.

Galderisi, A. (2011). Sustainable urban mobility: Current strategies \& new challenges for European cities. TeMA: Journal of Land Use, Mobility \& Environment, 4(2), 35-45.

Kittelson \& Associates, H.S. Levinson Transportation Consultants \& DMJM+Harris. 2007. TCRP Report 118: Bus Rapid Transit: Practitioner's Guide. Washington: Transportation Research Board.

Kubota, F. I., Ferenhof, H. A., Ferreira, M. G. G., Forcellini, F. A. \& Miguel, P. A. C. (2013). Desenvolvimento de Plataforma de Produto e Modularidade: Uma análise bibliométrica. Teoria e Prática em Administração, 3(2), 44-69.

Lee, S. Y., Jung, H. Y. \& Lee, J. H. (2011). Introduction of Bus Rapid Transit in a metropolitan area: The case of Busan metropolitan. Journal of the Eastern Asia Society for Transportation Studies, 9, 1160-1169.

Mejia-Dugand, S., Hjelm, O., Baas, L. \& Rios, R. A. (2013). Lessons from the spread of Bus Rapid Transit in Latin America. Journal of Cleaner Production, 50(1), 82-90.

Munoz-Raskin, R. (2010). Walking accessibility to Bus Rapid Transit: Does it affect property values? The case of Bogotá, Colombia. Transport Policy, 17(2), 72-84.

Murça, M. C. R., Müller, C. (2014). Urban public transportation: a demand analysis for the city of Salvador. Journal of Transport Literature, $8(1), 265-284$.

Neuenfeldt Júnior, A. L., De Paris, S. R., Siluk, J. C. M., Soliman, M., Machado, C. M. (2015). O uso da mensuração de desempenho para a comparação dos sistemas de transportes urbanos públicos. Perspectivas em Gestão \& Conhecimento, 5(1), 1.

NTU (2011). Estudos de BRT no Brasil. Brasília (BR): Secretaria Nacional de Transporte e da Mobilidade Urbana.

Nugem, R. C., Santos, C. H. S. \& De Oliveira, C. C. (2012). Transporte Coletivo e Saúde: Uma questão de gestão. Revista da Universidade Vale do Rio Verde, 10(1), 186-198.

Oliveira, E. K. F. \& Boente, D. R. (2012). Análise bibliométrica da produção científica recente sobre contabilidade gerencial. Organizações em contexto, 8(15), 199-212.

Pizzani, L., Da Silva, R. C. \& Hossne, W. S. (2010). Análise bibliométrica dos 40 anos da produção científica em bioética no Brasil e no Mundo. Revista Bioethikos, 4(4), 453-460.

Rezende, M. A., Frasson, A. C., Pilatti, L. A., Kovaleski, J. L. \& De Macedo, D.C. (2012). Transporte público para Copa do Mundo de 2014 no Brasil: Perspectivas, tendências e o caso de Curitiba. Espacios, 33(3), 25.

Schmid, V. (2014). Hybrid Large Neighborhood Search for the Bus Rapid Transit Route Design Problem. European Journal of Operational Research, 238(2), 427-437.

Tirachini, A., Hensher, D.A. \& Jara-Díaz, S.R. (2010). Comparing operator \& users costs of light rail, heavy rail \& Bus Rapid Transit over a radial public transport network. Research in Transportation Economics, 29(1), 231-242.

Tirachini, A., Hensher, D. A. \& Jara-Diaz, S. R. (2010). Restating modal investment priority with an improved model for public transport analysis. Transportation Research Part E, 46(6), 1148-1168.

Tirachini, A. \& Hensher, D. A. (2011). Bus congestion, optimal infrastructure investment \& the choice of a fare collection system in dedicated bus corridors. Transportation Research Part B, 45(5), 828-844.

Tirachini, A., Hensher, D. A. \& Rose, J.M. (2014). Multimodal pricing \& optimal design of urban public transport: The interplay between traffic congestion \& bus crowding. Transportation Research Part B, 61, 33-54.

UFPR (2012). Departamento de Transportes. Apostila Transporte Público. Curitiba (BR): UFPR.

Vasconcellos, E.A. (2012). Mobilidade urbana e cidadania. São Paulo (BR): Senac.

Wright, L. \& Hook, W. (2007). Manual de BRT: Guia de Planejamento. Brasília (BR): Secretaria Nacional de Transporte e da Mobilidade Urbana.

Yoshida, N. D. (2010). Análise bibliométrica: Um estudo aplicado à previsão tecnológica. Future Studies Research Journal, $2(1)$, 52-85. 